\title{
Mediastinal Leiomyosarcoma
}

National Cancer Institute

\section{Source}

National Cancer Institute. Mediastinal Leiomyosarcoma. NCI Thesaurus. Code C6619.

An aggressive malignant smooth muscle neoplasm, arising from the mediastinum. It is characterized by a proliferation of neoplastic spindle cells. 